Article

\title{
Antimicrobial Effects of Basil, Summer Savory and Tarragon Lyophilized Extracts in Cold Storage Sausages
}

\author{
Artur Macari ${ }^{1}$, Rodica Sturza ${ }^{1, *(\mathbb{D}}$, Ildiko Lung ${ }^{2, *}$, Maria-Loredana Soran ${ }^{2}{ }^{\mathbb{D}}$, Ocsana Opriş ${ }^{2}$, Greta Balan ${ }^{3}$, \\ Aliona Ghendov-Mosanu ${ }^{1}\left[{ }^{\circ}\right.$, Dan Cristian Vodnar ${ }^{4}\left(\mathbb{D}\right.$ and Daniela Cojocari ${ }^{3}$ \\ 1 Faculty of Food Technology, Technical University of Moldova, 9/9 Studentilor Street, MD-2045 Chisinau, \\ Moldova; artur.macari@tpa.utm.md (A.M.); aliona.mosanu@tpa.utm.md (A.G.-M.) \\ 2 National Institute for Research and Development of Isotopic and Molecular Technologies, \\ 400293 Cluj-Napoca, Romania; loredana.soran@itim-cj.ro (M.-L.S.); ocsana.opris@itim-cj.ro (O.O.) \\ 3 Department of Preventive Medicine, "Nicolae Testemitanu State" University of Medicine and Pharmacy, \\ 165 Stefan cel Mare Bd., MD-2004 Chisinau, Moldova; greta.balan@usmf.md (G.B.); \\ daniela.cojocari@usmf.md (D.C.) \\ 4 Faculty of Food Science and Technology, University of Agricultural Sciences and Veterinary Medicine, \\ 3-5 Manăştur Street, 400372 Cluj-Napoca, Romania; dan.vodnar@usamvcluj.ro \\ * Correspondence: rodica.sturza@chim.utm.md (R.S.); ildiko.lung@itim-cj.ro (I.L.)
}

\section{check for} updates

Citation: Macari, A.; Sturza, R.; Lung, I.; Soran, M.-L.; Opriş, O.; Balan, G.; Ghendov-Mosanu, A.; Vodnar, D.C.; Cojocari, D.

Antimicrobial Effects of Basil, Summer Savory and Tarragon Lyophilized Extracts in Cold Storage Sausages. Molecules 2021, 26, 6678. https://doi.org/10.3390/ molecules26216678

Academic Editor: Changsheng Zhang

Received: 30 September 2021 Accepted: 1 November 2021 Published: 4 November 2021

Publisher's Note: MDPI stays neutral with regard to jurisdictional claims in published maps and institutional affiliations.

Copyright: (c) 2021 by the authors. Licensee MDPI, Basel, Switzerland. This article is an open access article distributed under the terms and conditions of the Creative Commons Attribution (CC BY) license (https:/ / creativecommons.org/licenses/by/ $4.0 /)$.

\begin{abstract}
The problem of functional foods with bioactive components of natural origin is current for the food industry. Plant extracts rich in polyphenols with antioxidant and antimicrobial activity are a promising source for use in improving the quality and characteristics of fresh meat and meat products. In this context, the purpose of the present study was to evaluate the physico-chemical, microbiological, sensory properties of sausages prepared with the addition of lyophilized extract of basil, thyme or tarragon. For the beginning, the total amount of polyphenols, the antioxidant and antimicrobial activity of the extracts obtained from three spices were evaluated. In the sausages previously infected with Staphylococcus aureus and Escherichia coli it was observed that there is a much larger number of colonies of microorganisms in the control sample compared to the other samples within 24 and $48 \mathrm{~h}$. Moreover, following the addition of sausage extracts, no changes were found regarding their sensory acceptability.
\end{abstract}

Keywords: aromatic plants; extracts; antimicrobial activity; sausages; quality

\section{Introduction}

The functional foods are considered to be those foods that are intended to be consumed as part of the normal diet and that contain additional biologically active components that offer the potential for increased health or reduced risk of disease [1].

The interest for this category of food products has increased and the aim is to develop standards and guidelines for the development and promotion of such foods. Consumer interest in the relationship between food and health has grown substantially in Europe. There is a much broader recognition that today people can reduce the risk of disease and maintain their health and well-being through a healthy lifestyle, including diet.

The important role of foods such as fruits, vegetables, and whole grains in disease prevention, as well as the latest research on dietary antioxidants and combinations of plant protection substances, has provided an impulse for the development of the functional food market [2].

The use of plant extracts as a source of bioactive compounds is becoming an attractive strategy for improving the quality and characteristics of fresh meat and meat products [3]. Indeed, given their natural origins, bioactive compounds obtained from plants are ideal candidates to replace synthetic antioxidants (generally considered less safe) and to increase the shelf life of meat products. At the same time, these plant extracts can improve, either directly or indirectly, the functional value of meat products [4]. 
Antimicrobial compounds are used to inhibit the growth of microorganisms that induce food spoilage and antioxidants to retard lipid oxidation and discolouration of food $[5,6]$. Without food additives, adverse effects may be expected, such as more product recalls, an increased number of food-borne illness and subsequently increased the amount of food waste. Food producers therefore experience a severe limitation on the number of useful additives available. It is not possible to remove all preservatives without serious consequences on product safety and quality, but for the harmful effects of these compounds on humans, it is preferable to use the minimum quantities necessary for food preservation or changes with natural compounds. The challenge for clean label products is to find new food additives that meet both the food industry demand of having antioxidant and antimicrobial potency as well as consumer's demand of being natural without compromising sustainability [7].

The meat industry is an extremely important food sector in European countries and provides a nutritionally dense food that contains a wide range of nutrients such as proteins, lipids, vitamins and minerals. The meat sector has faced years of frequent crisis concerning safety, quality and negative publicity. It is therefore important to contribute to an increase in the confidence for meat as a healthy food choice. The microbial spoilage of minced meat products is a heterogeneous process that involves the development of diverse and poorly characterised microbial communities. Despite the fact that bacterial growth is one of the main factors that makes meat objectionable for human consumption, less is known about their community dynamics.

Extracts from various fruit and plants are known to contain candidates for natural food additives with antioxidant and antimicrobial activity [8], and having positive effects on colour.

Recently, researchers from the University of Aarhus in Denmark and Danish Meat Research Institute proposed the use of herbs and berries in organic meat products, starting from the fact that some berries, leaves, bulbs, roots, and stems of some plants are known for their content in substances with antibacterial and antiviral properties. In some plants, the concentration of these compounds is so high that they can probably be used to preserve food [9].

The research started with 37 species of plants whose antibacterial properties were tested on Listeria monocytogenes, Salmonella typhimurium and Escherichia coli, the list being finally reduced to eight species with demonstrable conservation capacities: aronia, sage, savory, blackthorn, cranberries, wild garlic, red currant, and horseradish [3,10].

Each of them can be added in various combinations and quantities in meat products for preservation, and in most cases, they add pleasant and desired flavours to the meat products. The researchers also aimed to develop optimal processing and storage methods so that the desired properties are preserved as long as possible after harvesting. It has also been investigated how a homogeneous distribution of preservatives in meat can be obtained if they are to be mixed in powder form into the product which presents a liquid form (suspension) [10,11].

A solution in this sense is the lyophilization of plants or of plant extracts with biological value to obtain high quality products. The original shape of the product is maintained, and by rehydration, a product with an excellent quality can be obtained [12,13]. Moreover, it is an excellent method for preserving a wide variety of heat-sensitive materials, such as proteins, vitamins, essential oils, tannins, antioxidants, pharmaceuticals, tissues, and plasma $[14,15]$.

The aim of this work was to study the addition effect of the lyophilized extract of basil, summer savory and tarragon on the physico-chemical quality indicators and microbiological activity of sausages. The spices chosen for this study were basil (Ocimum basilicul L.), summer savory (Satureja hortensis L.) and tarragon (Artemisia dracunculus L.) 


\section{Results}

\subsection{Plant Extracts Characterization}

\subsubsection{Total Phenolic Content}

The total phenolic content of the analysed extracts was calculated using the calibration curve, performed under the same conditions as the sample solutions. For the calibration curve, the solutions were prepared by successive dilutions, in the range $0.001-0.070 \mathrm{mg} / \mathrm{mL}$, from a standard solution of gallic acid with $1 \mathrm{mg} / \mathrm{mL}$ concentration. The equation of the calibration curve was $y=0.0133 x+0.0635$, with a correlation coefficient of 0.9993 . The results were expressed in $\mathrm{mg}$ gallic acid/g dry plant material. The total phenolic content obtained for basil and summer savory is presented in Figure 1.

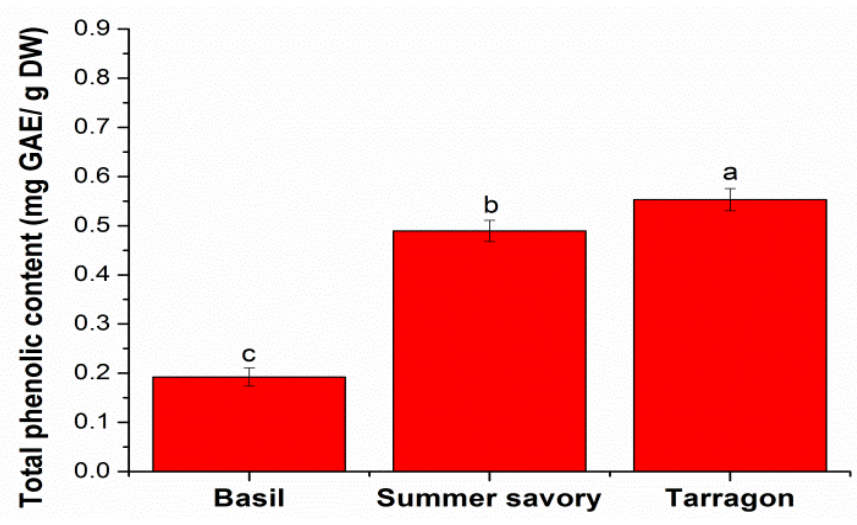

Figure 1. Comparative diagram of total phenolic content in the spices taken in study. Different letters $(\mathrm{a}, \mathrm{b}, \mathrm{c})$ mean significant differences between the spices, determined by Tukey's test $(p<0.05)$.

The total phenolic content of the spices taken into account in this study varies between 0.19-0.55 mg GAE/g DW depending on the plant. Thus, the largest total phenolic content was obtained for tarragon extract, followed by summer savory extract, while for basil extract was obtained for the smallest amount of the three spices. The amount of polyphenols varies on the origin of the plant, as well as on the extraction conditions. Thus, in other studies depending on solvent extraction and used technique, the total phenolic content obtained for basil was $1.325 \mathrm{~g} / 100 \mathrm{~g}$ DW with distilled water at $70{ }^{\circ} \mathrm{C}$ by infusion $15 \mathrm{~min}$ [16] and $516.35 \mathrm{mg} / 100 \mathrm{~g}$ DW with double-distilled water at $100{ }^{\circ} \mathrm{C}$ by infusion $15 \mathrm{~min}$ [17]. Total phenolic amounts between 63.2-109.6 mg GAE/100 g DW were obtained by extraction with $80 \%$ ethanol depending on the basil moisture [18]. Aburigal et al. [19] determined the total phenolic content obtained from basil plants were collected from a different region, by maceration in ethanol. They found it to vary from 0.408 to $0.881 \mathrm{mg} \mathrm{GAE} / \mathrm{g}$ DW depending on the region where it comes from. Chan et al. [20] reported that $0.45 \mathrm{mg} \mathrm{GAE} / \mathrm{g}$ DW was determined from extracts obtained by continuous shaking for $1 \mathrm{~h}$ at room temperature with methanol. Moreover, Słowianek and Leszczyńska [21] in the same condition, using 80\% methanol, found $26.50 \mathrm{mg} / \mathrm{g}$ DW. For tarragon, Petkova et al. [22] found $25 \mathrm{mg} \mathrm{GAE} / \mathrm{g}$ DW using ultrasound extraction and distilled water as solvent, while $58.03 \mathrm{mg}$ GAE/g DW was obtained using methanol as extraction solvent for extraction on magnetic shaker [23]. For summer savory, other authors found $12.14 \mathrm{mg}$ GAE/g DW using $60 \%$ aqueous ethanol as extraction solvent [24] and total phenolic amounts between 119.28-151.54 mg GAE/g DW depending on the used extraction technique and extraction solvent [25].

\subsubsection{Antioxidant Capacity}

The antioxidant capacity of the extracts was calculated from the calibration curve: $y=0.0016 x+0.0113$, with a correlation coefficient of 0.9990 . For this, the absorbances corresponding to solutions of different Trolox concentrations (0.004-3.2 mM) at a wavelength of $515 \mathrm{~nm}$ were read. Among the plants taken in this study (Figure 2), summer savory 
presented the highest antioxidant capacity (9.48 $\mathrm{mM}$ Trolox/g DW), followed by tarragon (4.77 mM Trolox/g DW) and then basil (1.96 mM Trolox/g DW).

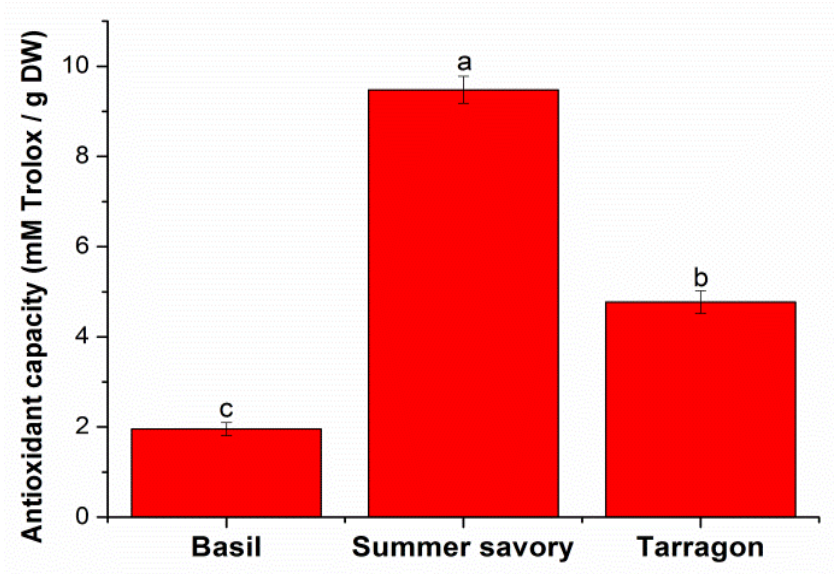

Figure 2. DPPH radical scavenging activity of studied spices. Different letters $(a, b, c)$ mean significant differences between the spices, determined by Tukey's test $(p<0.05)$.

\subsubsection{Antimicrobial Capacity}

All investigated plant extracts showed significant bioactivity against the tested enterobacteria like Listeria monocytogenes, Pseudomonas aeruginosa, Salmonella typhimurium, and Escherichia coli, when compared with streptomycin as control (Table 1). Considering Listeria monocytogenes, both basil and tarragon extracts exerted similar inhibitory (MIC) and bactericidal (MBC) activities, recording concentrations of $1.25 \mathrm{mg} / \mathrm{mL}$ and $2.5 \mathrm{mg} / \mathrm{mL}$, activities that were weaker than the antimicrobial activity of summer savory $(0.31 \mathrm{mg} / \mathrm{mL}$ and $0.62 \mathrm{mg} / \mathrm{mL}$ ). Pseudomonas aeruginosa were proved to be more sensitive to tarragon $(\mathrm{MIC}=2.5 \mathrm{mg} / \mathrm{mL}, \mathrm{MBC}=5 \mathrm{mg} / \mathrm{mL}$ ) than to basil and summer savory (MIC $=5 \mathrm{mg} / \mathrm{mL}$, $\mathrm{MBC}=10 \mathrm{mg} / \mathrm{mL}$ ). All the three extracts proved an identical antimicrobial capacity towards Salmonella typhimurium, recording a MIC of $5 \mathrm{mg} / \mathrm{mL}$ and MBC of $10 \mathrm{mg} / \mathrm{mL}$. Escherichia coli showed higher sensitivity to summer savory ( $\mathrm{MIC}=2.5 \mathrm{mg} / \mathrm{mL}, \mathrm{MBC}=5 \mathrm{mg} / \mathrm{mL}$ ) than to basil and tarragon (MIC $=5 \mathrm{mg} / \mathrm{mL}, \mathrm{MBC}=10 \mathrm{mg} / \mathrm{mL}$ ). According to the scientific literature, the microbial sensitivity of Listeria monocytogenes, Pseudomonas aeruginosa, Salmonella typhimurium, and Escherichia coli towards the alcoholic extracts of basil, summer savory, and tarragon are associated with the content of total phenolic compounds from the plant extracts, which act as antioxidants and cytoplasmic membrane destabilizing agents that lead to the bacterial cell death [26-29].

Table 1. Minimum inhibitory concentration (MIC) and minimum bactericidal concentration (MBC) of basil, summer savory, tarragon and streptomycin against bacterial strains tested with the microdilution method.

\begin{tabular}{|c|c|c|c|c|c|c|c|}
\hline \multirow[b]{2}{*}{ Bacterial Strain } & \multirow[b]{2}{*}{$\begin{array}{c}\text { Standard } \\
\text { Antibiotic }\end{array}$} & \multicolumn{3}{|c|}{$\mathrm{MIC}, \mathrm{mg} / \mathrm{mL}$} & \multicolumn{3}{|c|}{$\mathrm{MBC}, \mathrm{mg} / \mathrm{mL}$} \\
\hline & & Basil & $\begin{array}{c}\text { Summer } \\
\text { Savory }\end{array}$ & Tarragon & Basil & $\begin{array}{c}\text { Summer } \\
\text { Savory }\end{array}$ & Tarragon \\
\hline $\begin{array}{c}\text { Listeria } \\
\text { monocytogenes }\end{array}$ & 0.03 & 1.25 & 0.31 & 1.25 & 2.50 & 0.62 & 2.50 \\
\hline $\begin{array}{c}\text { Pseudomonas } \\
\text { aeruginosa }\end{array}$ & 0.12 & 5.00 & 5.00 & 2.50 & 10.00 & 10.00 & 5.00 \\
\hline $\begin{array}{l}\text { Salmonella } \\
\text { typhimurium }\end{array}$ & 0.12 & 5.00 & 5.00 & 5.00 & 10.00 & 10.00 & 10.00 \\
\hline Escherichia coli & 0.24 & 5.00 & 2.50 & 5.00 & 10.00 & 5.00 & 10.00 \\
\hline
\end{tabular}




\subsection{Plant Extracts Characterization}

The values of the quality indices of the sausages with the addition of lyophilized extracts of basil, summer savory and tarragon were evaluated in a comparison with the control sample (sausages obtained by the classic recipe), Table 2.

According to the organoleptic analysis within the organized tastings, the values of the appreciation score decrease compared to the value given to the control sample, the highest values were recorded for samples with the addition of summer savory $0.05-4.99 \%$ points, the addition of basil $0.1-4.95 \%$ points, and the addition of tarragon $0.1-4.89 \%$ compared to the control sample, which was assessed by 5.00 points according to the standard pre-assessment system. Higher concentrations of lyophilized additives from the above-mentioned plants are felt stronger organoleptically, which depreciates the value of a meat product.

According to the data presented in Table 2, the moisture content of the sausage samples corresponds to the regulated permitted values [19]. It was found that samples with the addition of plant extracts are characterized by a higher moisture content. In the control sample, the moisture content was $64.37 \%$, and in the samples with extracts, the increase in the value of this indicator was influenced by the concentration of the added extract. The samples with the highest extract concentration had the highest moisture content, thus SBE $(0.3 \%)-69.16 \%$; SSE $(0.2 \%)-71.48 \%$ and SET $(0.3 \%)-69.64 \%$. This phenomenon can be explained by the fact that lyophilized extracts contain polysaccharides, which have the ability to bind and retain water in sausages, thus preventing its removal in heat treatment. During storage under refrigeration conditions, the moisture content was reduced in all the samples analysed. This gradual decrease in moisture content during storage was due to the loss by evaporation through the packaging material. Similar results have been reported by Heena Sharma et al. (2017) in chicken sausages incorporated with holy basil, cloves, and cassia essential oil [30].

The $\mathrm{pH}$ of the sausage samples was influenced by the addition of plant extracts, Table 2. The concentrations of the added plant extracts were found to lead to the decrease in the $\mathrm{pH}$ values of the sausages. The lowest $\mathrm{pH}$ value was determined in the samples with the highest extract concentration. Thus, in the SBE $0.3 \%$ was 6.12 ; SSE $0.2-6.10 \%$ and in STE $0.3-6.12 \%$, while the $\mathrm{pH}$ of the control sample was 6.38 . During storage, the $\mathrm{pH}$ value increases in all the researched samples. We explain an increase in $\mathrm{pH}$ in supplemented sausages by influence of redox-transformations of phenolic compounds from Ocimum basilicum L., and Satureja hortensis L. extracts, in which they are very rich [30-33].

The complex mechanism of microbial suppression under the influence of phenols includes the participation of phenols in various redox processes [34-36]. The main version of these is that in which phenol, initially weak acid, is transformed to neutral quinone [36,37]. This process can be described by the following general equation:

$$
-\mathrm{OH} \stackrel{-\mathrm{e}^{-} ;-\mathrm{H}^{+}}{\rightarrow}=\mathrm{O}
$$

Factors affecting the leaching of matrix compounds may include the polarity of the medium used. The action of polyphenolic compounds in the matrix of meat products is stabilized by the nonpolar compositions. Polar environments, such as water, allow changes in the levels of phenolic compounds. In contrast, if the environment is non-polar, the loss of compounds is lower due to the lack of diffusion or migration to the environment [38].

The addition of basil, summer savory and tarragon extracts in different concentrations leads to a non-essential decrease in water activity $\left(a_{w}\right)$, Table 2. In the case of basil samples, the $\mathrm{a}_{\mathrm{w}}$ was not influenced by the increase in the concentration of added extracts, and in the case of summer savory samples, and tarragon, the value of this indicator varies from 0.876 c.u. up to 0.874 c.u. and from 0.874 c.u. up to 0.868 c.u. respectively. During storage, samples with extracts are characterized by values higher than $\mathrm{a}_{\mathrm{w}}$. These results are correlated with the data obtained for the moisture content of the sausages, which is higher in samples with the addition of extracts. 


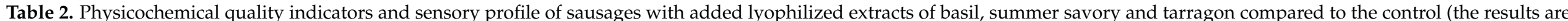
presented as means \pm standard deviation).

\begin{tabular}{|c|c|c|c|c|c|c|c|c|c|c|c|}
\hline Quality Indicators & Storage Time & Control & SBE 0.1\% & SBE 0.2\% & SBE 0.3\% & SSE 0.05\% & SSE 0.1\% & SSE $0.2 \%$ & STE 0.1\% & STE $0.2 \%$ & STE 0.3\% \\
\hline Moisture content, \% & $\begin{array}{l}\text { 1st day } \\
\text { 3rd day } \\
\text { 6th day }\end{array}$ & $\begin{array}{l}64.37 \pm 0.09 \mathrm{f} \\
58.1 \pm 0.15 \mathrm{~g} \\
54.89 \pm 0.15 \mathrm{~d}\end{array}$ & $\begin{array}{c}67.38 \pm 0.06 \mathrm{e} \\
59.3 \pm 0.03 \mathrm{f} \\
55.52 \pm 0.06 \mathrm{c}\end{array}$ & $\begin{array}{l}69.07 \pm 0.06 \mathrm{~d} \\
59.99 \pm 0.03 \mathrm{e} \\
55.57 \pm 0.06 \mathrm{c}\end{array}$ & $\begin{array}{c}69.16 \pm 0.15 \mathrm{c}, \mathrm{d} \\
61.06 \pm 0.09 \mathrm{c}, \mathrm{d} \\
55.94 \pm 0.12 \mathrm{~b}\end{array}$ & $\begin{array}{c}69.33 \pm 0.09 \mathrm{~b}_{\mathrm{b}, \mathrm{c}, \mathrm{d}} \\
59.32 \pm 0.15 \mathrm{f} \\
55.04 \pm 0.03 \mathrm{~d}\end{array}$ & $\begin{array}{c}69.44 \pm 0.06 \mathrm{~b}, \mathrm{c} \\
60.28 \pm 0.06 \mathrm{e} \\
55.11 \pm 0.09 \mathrm{~d}\end{array}$ & $\begin{array}{l}71.48 \pm 0.09 \mathrm{a} \\
60.78 \pm 0.03 \mathrm{~d} \\
55.83 \pm 0.03 \mathrm{~b}, \mathrm{c}\end{array}$ & $\begin{array}{c}69.48 \pm 0.12 \mathrm{~b} b \mathrm{c} \\
62.51 \pm 0.09 \mathrm{a} \\
55.74 \pm 0.12 \mathrm{~b}, \mathrm{c}\end{array}$ & $\begin{array}{l}69.56 \pm 0.03 \mathrm{~b} \\
62.16 \pm 0.06_{\mathrm{b}} \\
56.41 \pm 0.03 \mathrm{a}\end{array}$ & $\begin{array}{l}69.64 \pm 0.06 \mathrm{~b} \\
61.09 \pm 0.03 \mathrm{c} \\
55.55 \pm 0.06 \mathrm{c}\end{array}$ \\
\hline $\begin{array}{c}\text { Active } \\
\text { acidity } \mathrm{pH}\end{array}$ & $\begin{array}{l}\text { 1st day } \\
\text { 3rd day } \\
6 \text { th day }\end{array}$ & $\begin{array}{l}6.38 \pm 0.06 \mathrm{a} \\
6.40 \pm 0.06 \mathrm{a} \\
6.32 \pm 0.09 \mathrm{a}\end{array}$ & $\begin{array}{l}6.15 \pm 0.12 \mathrm{a} \\
6.17 \pm 0.09 \mathrm{a} \\
6.24 \pm 0.06 \mathrm{a}\end{array}$ & $\begin{array}{l}6.13 \pm 0.06 \mathrm{a} \\
6.26 \pm 0.06 \mathrm{a} \\
6.34 \pm 0.12 \mathrm{a}\end{array}$ & $\begin{array}{l}6.12 \pm 0.06 \mathrm{a} \\
6.22 \pm 0.09 \mathrm{a} \\
6.32 \pm 0.06 \mathrm{a}\end{array}$ & $\begin{array}{l}6.16 \pm 0.09 \mathrm{a} \\
6.33 \pm 0.03 \mathrm{a} \\
6.30 \pm 0.09 \mathrm{a}\end{array}$ & $\begin{array}{l}6.12 \pm 0.03 \mathrm{a} \\
6.24 \pm 0.12 \mathrm{a} \\
6.24 \pm 0.12 \mathrm{a}\end{array}$ & $\begin{array}{l}6.10 \pm 0.09 \mathrm{a} \\
6.28 \pm 0.12 \mathrm{a} \\
6.24 \pm 0.12 \mathrm{a}\end{array}$ & $\begin{array}{l}6.29 \pm 0.12 \mathrm{a} \\
6.41 \pm 0.12 \mathrm{a} \\
6.28 \pm 0.12 \mathrm{a}\end{array}$ & $\begin{array}{l}6.14 \pm 0.03 \mathrm{a} \\
6.33 \pm 0.09 \mathrm{a} \\
6.35 \pm 0.06 \mathrm{a}\end{array}$ & $\begin{array}{l}6.12 \pm 0.06 \mathrm{a} \\
6.28 \pm \pm 0.03 \mathrm{a} \\
6.26 \pm 0.12 \mathrm{a}\end{array}$ \\
\hline $\begin{array}{l}\text { Water activity } \\
\text { aw, c.u. }\end{array}$ & $\begin{array}{l}\text { 1st day } \\
\text { 3rd day } \\
6 \text { th day }\end{array}$ & $\begin{array}{l}0.875 \pm 0.003 \mathrm{a} \\
0.869 \pm 0.000 \mathrm{a} \\
0.866 \pm 0.000 \mathrm{a}\end{array}$ & $\begin{array}{l}0.873 \pm 0.003 \mathrm{a} \\
0.871 \pm 0.003 \mathrm{a} \\
0.869 \pm 0.000 \mathrm{a}\end{array}$ & $\begin{array}{l}0.873 \pm 0.003 \mathrm{a} \\
0.871 \pm 0.000 \mathrm{a} \\
0.869 \pm 0.003 \mathrm{a}\end{array}$ & $\begin{array}{l}0.873 \pm 0.003 \mathrm{a} \\
0.872 \pm 0.000 \mathrm{a} \\
0.870 \pm 0.003 \mathrm{a}\end{array}$ & $\begin{array}{l}0.876 \pm 0.003 \mathrm{a} \\
0.871 \pm 0.000 \mathrm{a} \\
0.869 \pm 0.003 \mathrm{a}\end{array}$ & $\begin{array}{l}0.875 \pm 0.002 \mathrm{a} \\
0.871 \pm 0.003 \mathrm{a} \\
0.869 \pm 0.000 \mathrm{a}\end{array}$ & $\begin{array}{l}0.874 \pm 0.000 \mathrm{a} \\
0.869 \pm 0.003 \mathrm{a} \\
0.869 \pm 0.002 \mathrm{a}\end{array}$ & $\begin{array}{l}0.874 \pm 0.000 \mathrm{a} \\
0.874 \pm 0.000 \mathrm{a} \\
0.874 \pm 0.003 \mathrm{a}\end{array}$ & $\begin{array}{l}0.871 \pm 0.003 \mathrm{a} \\
0.871 \pm 0.003 \mathrm{a} \\
0.871 \pm 0.003 \mathrm{a}\end{array}$ & $\begin{array}{l}0.868 \pm 0.003 \mathrm{a} \\
0.868 \pm 0.003 \mathrm{a} \\
0.868 \pm 0.003 \mathrm{a}\end{array}$ \\
\hline $\begin{array}{c}\text { Average score of sensory profile } \\
\text { Exterior appeaance } \\
\text { Color and appearance in section } \\
\text { Odor } \\
\text { Taste } \\
\text { Cosistency }\end{array}$ & 3rd day & $\begin{array}{l}5.00 \pm 0.00 \mathrm{a} \\
5.00 \pm 0.00 \mathrm{a} \\
5.00 \pm 0.00 \mathrm{a} \\
5.00 \pm 0.00 \mathrm{a} \\
5.00 \pm 0.00 \mathrm{a} \\
5.00 \pm 0.00 \mathrm{a}\end{array}$ & $\begin{array}{l}4.95 \pm 0.02 \mathrm{a}, \mathrm{b} \\
5.00 \pm 0.00 \mathrm{a} \\
5.00 \pm 0.00 \mathrm{a} \\
5.00 \pm 0.00 \mathrm{a} \\
4.75 \pm 0.11 \mathrm{~b} \\
4.99 \pm 0.01 \mathrm{a}\end{array}$ & $\begin{array}{c}4.68 \pm 0.03 \mathrm{c} \\
4.95 \pm 0.01 \mathrm{a}, \mathrm{b} \\
4.75 \pm 0.02 \mathrm{~b} \\
4.87 \pm 0.04 \mathrm{~b} \\
3.83 \pm 0.05 \mathrm{~d} \\
4.98 \pm 0.02 \mathrm{a} \mathrm{a}\end{array}$ & $\begin{array}{c}4.32 \pm 0.04 \mathrm{e} \\
4.90 \pm 0.03 \mathrm{~b}, \mathrm{c} \\
4.45 \pm 0.01 \mathrm{~d} \\
3.83 \pm 0.06 \mathrm{f} \\
3.46 \pm 0.07 \mathrm{e} \\
4.98 \pm 0.01 \mathrm{a}, \mathrm{b}\end{array}$ & $\begin{array}{c}.99 \pm 0.01 \mathrm{a}, \mathrm{b} \\
5.00 \pm 0.00 \mathrm{a} \\
5.00 \pm 0.00 \mathrm{a} \\
5.00 \pm 0.00 \mathrm{a} \\
4.95 \pm 0.02 \mathrm{a} \\
4.99 \pm 0.01 \mathrm{a}, \mathrm{b}\end{array}$ & $\begin{array}{r}4.66 \pm 0.03 \mathrm{c} \\
4.98 \pm 0.01 \mathrm{a} \\
4.75 \pm 0.02 \mathrm{~b} \\
4.37 \pm 0.02 \mathrm{~d} \\
4.27 \pm 0.08 \mathrm{c} \\
4.95 \pm 0.02 \mathrm{ab}\end{array}$ & $\begin{array}{c}4.35 \pm 0.03 \mathrm{e} \\
4.94 \pm 0.02 \mathrm{a}, \mathrm{b}, \mathrm{c} \\
4.60 \pm 0.05 \mathrm{c} \\
4.00 \pm 0.01 \mathrm{e} \\
3.35 \pm 0.10 \mathrm{e}, \mathrm{f} \\
4.87 \pm 0.07 \mathrm{~b}\end{array}$ & $\begin{array}{l}.89 \pm 0.01 \mathrm{~b} \\
5.00 \pm 0.00 \mathrm{a} \\
5.00 \pm 0.00 \mathrm{a} \\
4.75 \pm 0.02 \mathrm{c} \\
4.70 \pm 0.10 \mathrm{~b} \\
4.99 \pm 0.01 \mathrm{a}\end{array}$ & $\begin{array}{c}4.51 \pm 0.03 \mathrm{~d} \\
4.93 \pm 0.02 \mathrm{a}, \mathrm{b}, \mathrm{c} \\
4.50 \pm 0.02 \mathrm{c}, \mathrm{d} \\
3.83 \pm 0.04 \mathrm{f} \\
4.33 \pm 0.05 \mathrm{c} \\
4.98 \pm 0.02 \mathrm{a}, \mathrm{b}\end{array}$ & $\begin{array}{l}3.99 \pm 0.04 \mathrm{f} \\
4.87 \pm 0.05 \mathrm{c} \\
3.75 \pm 0.06 \mathrm{e} \\
3.63 \pm 0.02 \mathrm{~g} \\
3.25 \pm 0.05 \mathrm{f} \\
4.45 \pm 0.05 \mathrm{c}\end{array}$ \\
\hline
\end{tabular}

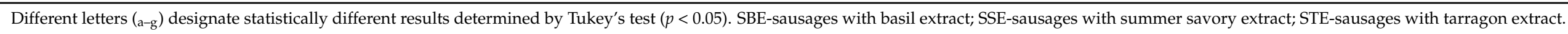


Water activity and $\mathrm{pH}$ are important physicochemical indicators that determine whether a sausage sample will condition the growth of pathogenic microorganisms [39]. The growth of microorganisms was certified both in the control sample and in the sausage samples with the addition of basil, summer savory and tarragon. The experimental data in Table 3 represent the growth rate of the identified microorganisms after $24 \mathrm{~h}, 96 \mathrm{~h}$ ( 4 days) and $168 \mathrm{~h}$ (7 days) after manufacture.

Table 3. The identified microorganisms after a period of time since the manufacture of sausages.

\begin{tabular}{|c|c|c|c|c|}
\hline Sample/Storage Time & TNMAFA, CFU/g & Coliforms Bacteriain $1 \mathrm{~g}$ & $\begin{array}{l}\text { Staphylococcus aureus } \\
\text { in } 1 \mathrm{~g}\end{array}$ & $\begin{array}{l}\text { Salmonella spp. } \\
\quad \text { in } 25 \mathrm{~g}\end{array}$ \\
\hline \multicolumn{5}{|c|}{ After $24 \mathrm{~h}$} \\
\hline Control & $10^{3}$ & - & - & - \\
\hline SBE $0.1 \%$ & $10^{3}$ & - & - & - \\
\hline SBE $0.2 \%$ & $10^{3}$ & - & - & - \\
\hline SBE $0.3 \%$ & $10^{3}$ & - & - & - \\
\hline SSE $0.05 \%$ & $10^{3}$ & - & - & - \\
\hline SSE $0.1 \%$ & $10^{2}$ & - & - & - \\
\hline SSE $0.2 \%$ & $10^{3}$ & - & - & - \\
\hline SET $0.1 \%$ & $10^{3}$ & - & - & - \\
\hline SET $0.2 \%$ & $10^{3}$ & - & - & - \\
\hline SET $0.3 \%$ & $10^{2}$ & - & - & - \\
\hline \multicolumn{5}{|c|}{ After 96 h (4 days) } \\
\hline Control & $10^{4}$ & - & - & - \\
\hline SBE $0.1 \%$ & $10^{3}$ & - & - & - \\
\hline SBE $0.2 \%$ & $10^{3}$ & - & - & - \\
\hline SBE $0.3 \%$ & $10^{2}$ & - & - & - \\
\hline SSE $0.05 \%$ & $10^{3}$ & - & - & - \\
\hline SSE $0.1 \%$ & $10^{3}$ & - & - & - \\
\hline SSE $0.2 \%$ & $10^{3}$ & - & - & - \\
\hline SET $0.1 \%$ & $10^{2}$ & - & - & - \\
\hline SET $0.2 \%$ & $10^{3}$ & - & - & - \\
\hline SET $0.3 \%$ & $10^{4}$ & - & - & - \\
\hline \multicolumn{5}{|c|}{ After 168 h (7 days) } \\
\hline Control & $10^{5}$ & - & - & - \\
\hline SBE $0.1 \%$ & $10^{4}$ & - & - & - \\
\hline SBE $0.2 \%$ & $10^{3}$ & - & - & - \\
\hline SBE $0.3 \%$ & $10^{4}$ & - & - & - \\
\hline SSE $0.05 \%$ & $10^{4}$ & - & - & - \\
\hline SSE $0.1 \%$ & $10^{4}$ & - & - & - \\
\hline SSE $0.2 \%$ & $10^{4}$ & - & - & - \\
\hline SET $0.1 \%$ & $10^{4}$ & - & - & - \\
\hline SET $0.2 \%$ & $10^{4}$ & - & - & - \\
\hline SET $0.3 \%$ & $10^{5}$ & - & - & - \\
\hline
\end{tabular}

TNMAFA-total number of mesophilic aerobic and facultative anaerobic bacteria; "-" absence of growth; CFU—colony forming unit. SBE—sausages with basil extract; SSE—-sausages with summer savory; STE—sausages with tarragon.

After $24 \mathrm{~h}$ from manufacture all samples corresponded to microbiological standard indicators; coliforms bacteria, Staphylococcus aureus or Salmonella spp. we not detected.

After $96 \mathrm{~h}$ (4 days) from manufacture in the control sample and the one with $0.3 \%$ tarragon content and a number of $10^{4} \mathrm{CFU}$ were identified; this exceeds the normative requirements. Coliforms bacteria, Staphylococcus aureus or Salmonella spp. were not detected.

After 7 days (168 h) from manufacture, in all samples a number of CFUs were identified that exceeded the normative requirements, except for the sample with $0.2 \%$ basil [39]. Coliform bacteria, Staphylococcus aureus or Salmonella spp. were not detected. 
Sausages previously infected with standard strains Staphylococcus aureus ATCC 25923 and Escherichia coli ATCC 25922 were investigated for the growth rate of pathogenic microorganisms within $24 \mathrm{~h}$ and $48 \mathrm{~h}$.

According to the obtained results, a higher number of colonies is observed in the control sample compared to the samples containing extracts. In the SBE samples less number of colonies for Staphylococcus aureus was observed after $48 \mathrm{~h}$, and for Gram-negative bacilli the basil extracts showed a higher activity after $24 \mathrm{~h}$. Basil extracts in concentrations of $0.1 \%$ and $0.3 \%$ were more active on Staphylococcus aureus, but concentrations of $0.2 \%$ and $0.3 \%$ had activity on Gram-negative bacilli. Summer savory and tarragon extracts had a more pronounced activity after $24 \mathrm{~h}$ on all species of bacteria tested. The summer savory extract in concentrations of $0.1 \%$ and tarragon extract in concentrations of $0.2 \%$ and $0.3 \%$ showed a more pronounced antimicrobial activity (Table 4). Probably, the microbial development in sausages, kept cold, is influenced not only by quality physicochemical indicators such as moisture content, water activity and $\mathrm{pH}$, but also by the antimicrobial activity of the added extracts [40].

Table 4. The results of in situ monitoring of growing pathogenic strains.

\begin{tabular}{|c|c|c|c|c|}
\hline \multirow{2}{*}{ Sample } & \multicolumn{2}{|c|}{$\begin{array}{c}\text { Staphylococcus aureus } \\
\mathrm{mln} / \mathrm{g}\end{array}$} & \multicolumn{2}{|c|}{$\begin{array}{l}\text { Escherichia coli } \\
\mathrm{mln} / \mathrm{g}\end{array}$} \\
\hline & $24 \mathrm{~h}$ & $48 \mathrm{~h}$ & $24 \mathrm{~h}$ & $48 \mathrm{~h}$ \\
\hline Control & 320 & 650 & 528 & 788 \\
\hline SBE $0.1 \%$ & 312 & 26 & 67 & 232 \\
\hline SBE $0.2 \%$ & 286 & 160 & 52 & 184 \\
\hline SBE $0.3 \%$ & 242 & 74 & 46 & 242 \\
\hline SSE $0.05 \%$ & 263 & 316 & 216 & 244 \\
\hline SSE $0.1 \%$ & 146 & 136 & 104 & 103 \\
\hline SSE $0.2 \%$ & 102 & 216 & 88 & 196 \\
\hline SET $0.1 \%$ & 316 & 236 & 146 & 702 \\
\hline SET $0.2 \%$ & 206 & 256 & 128 & 248 \\
\hline SET $0.3 \%$ & 112 & 221 & 106 & 256 \\
\hline
\end{tabular}

SBE—-sausages with basil extract; SSE—sausages with summer savory extract; STE—sausages with tarragon extract.

In the control sample it was determined more colonies of microorganisms compared to the other samples. In the samples of sausages with summer savory extract there is a diminished growth of Staphylococcus aureus strain, especially in the sample with a concentration of $0.2 \%$ summer savory. In the samples of sausages SBE $0.2 \%$ and SSE $0.2 \%$, a smaller number of colonies of the genus Escherichia coli were observed.

There is a growing number of evidence that flavonoids have antibacterial activity against both Gram-positive and Gram-negative bacteria. The mechanisms of action of phenolic compounds on the bacterial cell have been partly attributed to damage the bacterial membrane, inhibition of virulence factors such as enzymes and toxins, and suppression of bacterial biofilm formation [41].

When evaluating the antimicrobial effect of different quantities of Satureja montana L. essential oil against Clostridium perfringens type A inoculated in mortadella-type sausages with different concentrations of sodium nitrite stored at $25^{\circ} \mathrm{C}$ for 30 days, the population of target microorganisms was reduced compared to control samples [31]. In order to obtain safe products, with the use of natural additives the basil essential oil was added in the Italian-type sausage which showed a positive influence on reducing the count of Staphylococcus aureus until the 14th day of storage [40]. The addition of Juniperus communis L. essential oil at concentrations of $0.01,0.05$ and $0.10 \mu \mathrm{L} / \mathrm{g}$ to dry fermented sausage resulted in satisfying physico-chemical properties and improved oxidative stability [33]. 


\section{Materials and Methods}

\subsection{Hydroalcoholic Extract Preparation}

The plant material used in this study, basil (Kamis-Condimente SRL, Bucuresti, Romania), summer savory (Kamis-Condimente SRL, Bucuresti, Romania) and tarragon (KamisCondimente SRL, Bucuresti, Romania), was purchased from the local supermarket.

The powder obtained after plant pulverization with a grinder, was subjected to ultrasonic-assisted extraction with $80 \%$ ethanol, the ratio between plant and extraction solvent being 1:5 (w/v). The extractions were performed in a Transsonic T 310 ultrasonic bath, at room temperature for $30 \mathrm{~min}$. The obtained extracts were centrifuged and stored at $4{ }^{\circ} \mathrm{C}$ until analysis. All the extracts were performed in triplicate.

In order to incorporate the extracts into the sausages, they were concentrated up to $10 \%$, to remove the alcohol and then lyophilized.

\subsection{Characterization of the Obtained Extracts}

\subsubsection{Total Phenolic Content}

An T80 UV-VIS spectrophotometer (PG Instruments Limited) was used to determine the total polyphenol content of the obtained extracts, using the Folin-Ciocâlteu method [42]. This method is based on the chemical reduction of the Folin-Ciocâlteu reagent, the resulting products giving a blue colored compound which is represented by a wide absorption band with a maximum of $765 \mathrm{~nm}$. Thus, in a volumetric flask $(10 \mathrm{~mL})$ containing $5 \mathrm{~mL}$ of double-distilled water, $10 \mu \mathrm{L}$ of extract and $0.5 \mathrm{~mL}$ of Folin-Ciocâlteu reagent were added. The obtained mixture was left to stand for $3 \mathrm{~min}$, after which $1.5 \mathrm{~mL}$ of $\mathrm{Na}_{2} \mathrm{CO}_{3}(5 \mathrm{~g} / \mathrm{L})$ and bidistilled water up to $10 \mathrm{~mL}$ were added. The samples were stored at $50{ }^{\circ} \mathrm{C}$ (in a water bath) for $16 \mathrm{~min}$ in closed flasks, after that these were cooled to room temperature and their absorbance was read relative to the blank sample (double-distilled water). The total phenolic content was expressed as gallic acid equivalents (GAE) per $1 \mathrm{~g}$ of dried weight (DW) of plant.

\subsubsection{Antioxidant Capacity}

The antioxidant capacity of the obtained extracts was determined by DPPH method (2,2'-diphenyl-picrylhydrazyl), following a slightly modified procedure reported by BrandWilliams et al. [43].

In order to determine the antioxidant capacity, a volume of $0.01 \mathrm{~mL}$ extract was added to $3.9 \mathrm{~mL}$ of DPPH radical solution $(0.0025 \mathrm{~g} / 100 \mathrm{~mL}$ of methanol). The resulting mixture was kept in the dark for $10 \mathrm{~min}$, after which the absorbance of the mixture was measured at $515 \mathrm{~nm}$ to the control sample $(0.01 \mathrm{~mL}$ extract added to $3.9 \mathrm{~mL}$ methanol). The results were expressed in $\mathrm{mM}$ Trolox/g dry plant material.

\subsubsection{Antimicrobial Activity}

For the bioassay four bacterial strains Listeria monocytogenes (ATCC 19114), Pseudomonas aeruginosa (ATCC 27853), Salmonella typhimurium (ATCC 14028) and Escherichia coli (ATCC 25922) were taken into -account for this study. All of the tested microorganisms were obtained from Food Biotechnology Laboratory, Life Sciences Institute, University of Agricultural Sciences and Veterinary Medicine Cluj Napoca, Romania. For the antimicrobial activity evaluation, the obtained extract was evaporated to dryness under reduced pressure at $30^{\circ} \mathrm{C}$ and re-suspended in $5 \mathrm{~mL}$ of bidistilled water.

Evaluation of the antimicrobial activity was done according to the guidelines of the Clinical Laboratory Standards Institute (CLSI) [44] using the standard broth microdilution technique, with few modifications. The bacteria were cultured on Muller-Hinton Agar and cultures were stored at $4{ }^{\circ} \mathrm{C}$ and subcultured once a month. The medium used for susceptibility testing was Tryptic Soy Broth (TSB) medium. Before antibacterial susceptibility testing, each aerobic bacteria was cultured overnight at $37^{\circ} \mathrm{C}$ on Tryptic Soy Broth (TSB) medium. The bacterial cell suspensions were adjusted with sterile saline to a concentration of approximately $2 \times 10^{5} \mathrm{CFU} / \mathrm{mL}$ in a final volume of $100 \mu \mathrm{L}$ per well. The inoculum 
was stored at $+4{ }^{\circ} \mathrm{C}$ for further use. Dilutions of the inoculums were cultured on solid Muller-Hinton (MH) to verify the absence of contamination of bacteria and to check the validity of the inoculums. Determinations of minimum inhibitory concentrations (MICs) were performed by a serial dilution technique using 96-well microtitre plates. The $100 \mu \mathrm{L}$ Mueller-Hinton broth was placed into each of the 96 wells of the microplates. Aliquots of $100 \mu \mathrm{L}$ of each ethanolic extract were added into the first rows of the microplates and twofold dilutions of the extracts were made by dispensing the solutions into the remaining wells. Afterwards, $10 \mu \mathrm{L}$ of inoculum were added to all the wells. We used ethanol $(40 \%)$ in water as a control. The microplates were incubated for $24-48 \mathrm{~h}$ at $37^{\circ} \mathrm{C}$. The MIC of the samples was detected following the addition of $20 \mu \mathrm{L}(0.2 \mathrm{mg} / \mathrm{mL})$ of resazurin solution to each well, and the plates were incubated $2 \mathrm{~h}$ at $37^{\circ} \mathrm{C}$. A change from blue to pink indicates reduction of resazurin and therefore bacterial growth. The MIC was defined as the lowest extract concentration that prevented this colour change, therefore inhibited the growth of the bacterial strain [45]. The minimum bactericidal concentrations (MBCs) were determined by serial subcultivation of a $2 \mu \mathrm{L}$ into 96 -microtitre plates containing $100 \mu \mathrm{L}$ of $\mathrm{MH}$ broth per well and further incubation for $48 \mathrm{~h}$ at $37^{\circ} \mathrm{C}$. The lowest concentration of tested extract/compound/antibiotic with no visible bacteria growth was defined as MBC, indicating 99.5\% killing of the original inoculum [45]. Streptomycin (Sigma P 7794, Santa Clara, CA, USA) $(0.05-3 \mathrm{mg} / \mathrm{mL})$ was used as positive control for bacterial growth. A $10 \%$ solution of ethanol in water was used as negative control.

\subsection{Sausages Preparation}

The sausage samples were prepared in laboratory conditions (semi-industrial) according to classic technology of manufacturing "Lacta" sausages, included in the group of boiled sausages. According to the recipe, expressed in kilograms of raw materials required to obtain $100 \mathrm{~kg}$ of the finished product $(\mathrm{kg} / 100 \mathrm{~kg})$, sausages were obtained from high quality beef $(35 \mathrm{~kg})$, semi-fat pork $(48 \mathrm{~kg})$, fatty pork $(12 \mathrm{~kg})$, powdered milk $(2 \mathrm{~kg})$, eggs $(3 \mathrm{~kg})$ is mixed with spices and auxiliary materials consisting of salt $(1.87 \mathrm{~kg})$, sugar $(0.12 \mathrm{~kg})$, ground black or white pepper $(0.12 \mathrm{~kg})$ and nutmeg $(0.04 \mathrm{~kg})$. Also, $25 \%$ ice was added to the sausage's composition.

The control sample was obtained according to the classical unmodified technology. Subsequently, samples were prepared with lyophilized basil extracts $0.1 \%, 0.2 \%, 0.3 \%$ and summer savory $0.05 \%, 0.1 \%, 0.2 \%$ and tarragon $0.1 \%, 0.2 \%, 0.3 \%$. The lyophilized extracts from the mentioned plants were rehydrated and added to the composition at the technological stage of cutterization and homogenization. The composition was mechanically stuffed into polyamide membrane. Sausages were cooked by steam at $83 \pm 2{ }^{\circ} \mathrm{C}$ for $40 \mathrm{~min}$ to an internal temperature of $72^{\circ} \mathrm{C}$. After steam cooking, samples were immediately chilled with cold water shower. Finally, the sausages were stored at $4 \pm 1^{\circ} \mathrm{C}$ for 6 days.

\subsection{Sausages Quality Analysis}

The sausages were analyzed on the 1st, 3rd, and 6th days from production date in order to study the parameters' evolution during storage. Quality indicators were determined by international standardized methods. The values of the quality indicators are regulated by legislation [39].

\subsubsection{Sensory Analysis of Sausages}

Standard ISO 6658:2017 [46] was followed when performing the sensory analysis of the products. Exterior appearance, color in section, taste, odor, and consistency were assessed using the 5-point system by an expert panel of eleven trained food technologists (Staff of Department of Food Technology, Faculty of Food Technology, Technical University of Moldova). The 5-point assessment system includes the following scores: 5-very good; 4-good, 3-satisfactory, 2-poor, 1-bad. Table 5 shows the sensory characteristics of sausages. 
Table 5. The sensory characteristics for the evaluation of sausages.

\begin{tabular}{|c|c|}
\hline Sensory Characteristic & Product Description \\
\hline Exterior appearance & $\begin{array}{l}\text { Small sticks with a clean, dry surface, without stains, } \\
\text { adhesions, affluences of composition and ruptures of } \\
\text { the membrane. The ends of the membranes of small } \\
\text { bars are twisted or tied with string or thread. } \\
\text { The color of the composition from light pink } \\
\text { (control) to the color characteristic of the type of } \\
\text { plant extract, finely chopped with pieces of food }\end{array}$ \\
\hline Color and appearance in section & $\begin{array}{l}\text { ingredients other than meat, according to the recipe, } \\
\text { mixed evenly and without gaps. The presence of fine } \\
\text { porosity in the form of gaps and the insignificant } \\
\text { presence of coarse connective tissue are allowed. }\end{array}$ \\
\hline Odor & $\begin{array}{l}\text { Characteristic of the type of product with an odor of } \\
\text { respective plant extract, without a foreign odor. }\end{array}$ \\
\hline Taste & $\begin{array}{l}\text { Characteristic of the type of product with a taste of } \\
\text { respective plant extract, without foreign taste. }\end{array}$ \\
\hline Consistency & Fine, juicy (hot) \\
\hline
\end{tabular}

\subsubsection{Moisture Content}

The mass fraction of moisture was determined by drying in an oven (gravimetric method). The method is based on the weight loss of the sample to constant mass, due to the evaporation of water by heating in oven at $103 \pm 2{ }^{\circ} \mathrm{C}$ at atmospheric pressure [47].

\subsection{3. $\mathrm{pH}$ Determination}

The $\mathrm{pH}$ was determined by the express method using the Testo $205 \mathrm{pH}$ meter (Testo Ltd., Alton, UK), used for determinations in semi-solid substances in food production and processing.

\subsubsection{Water Activity Determination}

The determination of water activity $\left(\mathrm{a}_{\mathrm{w}}\right)$ was performed by the express method using the LabSwift-aw device (Novasina AG, Lachen, Switzerland), specially designed to determine the free water fraction in a test sample such as foods, cosmetics, or pharmaceuticals.

\subsection{Microbiological Analysis of the Sausages}

Sausages with the addition of lyophilized plant extracts were subjected to microbiological examination with the investigation of the total number of aerobic mesophilic microorganisms (TNGs), which provides data on the contamination degree of the product, coliforms bacteria which indicates the fecal contamination and pathogenic microorganism's detection of the Staphylococcus and Salmonella genus. The microbiological indicators were determined by international standardized methods.

\subsubsection{TNG Determination}

The method consists of the determination of the mesophilic aerobic organotrophic bacteria and it is based on the fact that the microbial cells present in the test sample, in contact with the solidified peptone agar, will each form visible colonies, after incubation at $30{ }^{\circ} \mathrm{C}$ for $48-72 \mathrm{~h}$. It is also known as TNG (total number of germs). Taking into account the decimal dilution used and the number of colonies forming units (CFU), the number of microorganisms per gram produced is determined. This test was performed in accordance with SM EN ISO 4833-1 [48].

\subsubsection{Coliforms Bacteria Determination}

Coliforms bacteria are bacteria that grow / develop in the specific temperature range of $35-37^{\circ} \mathrm{C}$, ferment lactose, with gas release when the analysis is performed on Coliforme 
MacConkey agar (lactose media) and under the conditions provided in the method specified according to SM ISO 4831/2006 [49].

\subsubsection{Staphylococcus Genus Determination}

From the prepared sample, from the $10^{-1}$ dilution is taken $10 \mathrm{~mL}$ (it corresponds to $1 \mathrm{~g}$ of the inoculated samples) and added to the Giolitti-Cantoni Broth-the enrichment medium - and incubated for $24 \mathrm{~h}$ at $37^{\circ} \mathrm{C}$. After $24-48 \mathrm{~h}$, the sample (Giolitti-Cantoni Broth) is inoculated on solid nutrient medium Baird Parker and is thermostated for $48 \mathrm{~h}$ at $37^{\circ} \mathrm{C}$. If there appears typical black colonies of $1.5-2.5 \mathrm{~mm}$ in diameter, with a lecithinase zone, then these colony are confirmed by a plasmacoagulase test.

The method of the Staphylococcus genus determination is based on the properties of the mannitol use under anaerobic conditions to produce the coagulase. Staphylococcus occurs in clusters formed by the cleavage of $0.8 \mu \mathrm{m}$ diameter spherical cells. It forms smooth, slightly convex, glossy colonies with a creamy consistency and regular edges. Colony pigmentation varies from white to golden yellow depending on the species. In liquid media they produce turbidity, an annular film and, over time, a dusty deposit and clarification of the liquid. They are facultatively anaerobic bacteria that grow to an optimal temperature of $30-37^{\circ} \mathrm{C}$ with an optimal $\mathrm{pH}$ of 7-7.5. Certain differential characters are used to diagnose species. $S$. aureus, unlike other Staphylococcus, produces phospholipoprotein lipase and can use egg yolks (lipolytic properties). It is tolerant to salt, lithium chloride, potassium thiocyanate, sodium azide, glycine, and polymyxin [49,50].

\subsubsection{Determination of Genus Salmonella}

Bacteria from genus Salmonella belong to Gram-negative rods, mobile, with peritrich cilia, facultative aerobic or anaerobic, which can multiply in culture media and in food and produces endotoxins. Normally, the number of bacteria belonging to the Salmonella genus in food is absent, these being associated with a numerous microflora in which enterobacteria is usually predominant.

In order to create favourable conditions for the Salmonella genus, to be detected in products, the microbiological analysis involves several steps consisting of inoculation into liquid nutrients without selectivity, inoculation into nutrients with different degrees of selectivity to promote Salmonella multiplication, inoculation on selective media and differentiation media for the isolation of colonies characteristic for the Salmonella genus and confirmation by biochemical and serological tests of species belonging to the Salmonella genus. The detection method of the Salmonella genus is provided in the standard SM EN ISO 6579-1: 2017 [51].

\subsection{Microbiological Analysis of the Infected (Contaminated) Sausages with Reference Strains}

The antibacterial activity of the basil, summer savory and tarragon extracts added to the sausages was determined in situ. The control sample and the samples with the addition of lyophilized plant extracts were previously infected with bacterial strains: Staphylococcus aureus and Escherichia coli.

$1.0 \mathrm{~g}$ of each sample was ground in a porcelain mortar and then $1 \mu \mathrm{L}$ of the bacterial cultures standardized according to the McFarland opalescence optical standard of turbidity (0.5) was added. Infected samples containing various plant extracts were prepared and incubated in thermostat at $37^{\circ} \mathrm{C}$ for 24 and $48 \mathrm{~h}$ in order to determine the antibacterial effect of extracts.

On the second day, decimal dilutions of each infected sample were made. Thus, to each $1 \mathrm{~g}$ of the infected sample, $9 \mathrm{~mL}$ of saline solution $(0.85 \% \mathrm{NaCl})$ was added. Six dilutions were done, after which from the dilutions -3 and $-6,2$ drops were inoculated on appropriate media for the tested strains. The samples were incubated at $37{ }^{\circ} \mathrm{C}$ for $24 \mathrm{~h}[52,53]$. 


\subsection{Statistical Analyses}

All calculations were done using Microsoft Office Excel 2007 (Microsoft, Redmond, WA, USA) and graphs were performed using ORIGIN8 (OriginLab Corporation, Northampton, MA, USA). Data obtained in this study are presented as mean values \pm the standard error of the mean calculated from 3 parallel experiments. The comparison of average values was based on the one-way analysis of variance (ANOVA) according to Tukey's test at significance level $p \leq 0.05$, using Minitab 17 programme (Minitab Ltd., Coventry, UK).

\section{Conclusions}

Plant extracts can be used as an ingredient or as a packaging component for short or long storage periods (such as for fresh meat and sausages). Finally, the search for effective and practicable solutions for the implementation of these extracts in active packaging is advisable and could find immense interest in the future.

As a result of the tests performed, it was established that vegetable additives-lyophilized extracts of basil and summer savory in the recipe for the manufacture of "Lacta" sausages can control the growth rate of microorganisms, including pathogenic ones. This was determined by evaluating the multiplication of strains of microorganisms such as Staphylococcus aureus and Escherichia coli.

The TNMAFA in samples with plant additives in different concentrations is much lower compared to the control sample. Infected strains in these samples show a directed progressive growth and development of microorganism's colonies.

Therefore, the use of vegetable additives in the recipe of meat products can mean two things: an improved nutritional value of the product and an increased shelf life of the product by keeping the microbiological risk under control.

Lyophilization is an advanced method that ensures the preservation of the biological value of products with a composition sensitive to high temperatures. By applying lyophilization on spice plants and plant extracts, the problem of the stability of bioactive compounds and subsequent application in food technologies in order to fortify food can be solved.

According to the organoleptic analysis within the organized tastings, the values of the appreciation score decreases compared to the value given to the control sample; the highest values were recorded for samples with the addition of summer savory $0.05-4.99 \%$ points, the addition of basil $0.1-4.95 \%$ points, and the addition of tarragon $0.1-4.89 \%$ compared to the control sample, which was assessed by 5.00 points according to the standard pre-assessment system. Higher concentrations of lyophilized additives from the above-mentioned plants are felt stronger organoleptically, which depreciates the value of a meat product.

Author Contributions: Conceptualization, A.M., M.-L.S. and R.S.; investigation, A.M., I.L., O.O., G.B., A.G.-M., D.C.V. and D.C.; writing—original draft preparation, A.M., G.B., A.G.-M., D.C.V., D.C. and I.L.; writing - review and editing, M.-L.S. and R.S.; visualization, R.S. and M.-L.S.; supervision, R.S. and M.-L.S. All authors have read and agreed to the published version of the manuscript.

Funding: This research received no external funding.

Institutional Review Board Statement: Not applicable.

Informed Consent Statement: Not applicable.

Data Availability Statement: Not applicable.

Acknowledgments: This work was supported by Moldova State project 20.80009.5107.09 “Improvement of food quality and safety by biotechnology and food engineering", running at Technical University of Moldova.

Conflicts of Interest: The authors declare no conflict of interest.

Sample Availability: Samples of the compounds are not available from the authors. 


\section{References}

1. Hasler, C.M. Functional Foods: Benefits, Concerns and Challenges-A Position Paper from the American Council on Science and Health. J. Nutr. 2002, 132, 3772-3781. [CrossRef] [PubMed]

2. Slavin, J.L.; Lloyd, B. Health Benefits of Fruits and Vegetables. Adv. Nutr. 2012, 3, 506-516. [CrossRef]

3. Bhat, Z.; Bhat, H. Functional Meat Products: A Review. Int. J. Meat Sci. 2010, 1, 1-14. [CrossRef]

4. Poltorak, A.; Marcinkowska-Lesiak, M.; Lendzion, K.; Onopiuk, A.; Moczkowska, M.; Wojtasik-Kalinowska, I.; Wierzbicka, A. The effect of bioactive components of plant origin on the physicochemical and sensory characteristics of functional sausages. Food Sci. Technol. 2019, 39, 232-239. [CrossRef]

5. Munekata, P.E.S.; Rocchetti, G.; Pateiro, M.; Lucini, L.; Domínguez, R.; Lorenzo, J.M. Addition of plant extracts to meat and meat products to extend shelf-life and health-promoting attributes: An overview. Curr. Opin. Food Sci. 2020, 31, 81-87. [CrossRef]

6. Smaoui, S.; Ben Hsouna, A.; Lahmar, A.; Ennouri, K.; Mtibaa-Chakchouk, A.; Sellem, I.; Najah, S.; Bouaziz, M.; Mellouli, L. Bio-preservative effect of the essential oil of the endemic Mentha piperita used alone and in combination with BacTN635 in stored minced beef meat. Meat Sci. 2016, 117, 196-204. [CrossRef]

7. Shah, M.A.; Bosco, S.J.D.; Mir, S.A. Plant extracts as natural antioxidants in meat and meat products. Meat Sci. 2014, 98, 21-33. [CrossRef] [PubMed]

8. Krishnan, K.R.; Babuskin, S.; Babu, P.A.S.; Sasikala, M.; Sabina, K.; Archana, G.; Sivarajan, M.; Sukumar, M. Antimicrobial and antioxidant effects of spice extracts on the shelf life extension of raw chicken meat. Int. J. Food Microbiol. 2014, 171, 32-40. [CrossRef] [PubMed]

9. Hung, Y.; de Kok, T.M.; Verbeke, W. Consumer attitude and purchase intention towards processed meat products with natural compounds and a reduced level of nitrite. Meat Sci. 2016, 121, 119-126. [CrossRef]

10. Mariem, C.; Sameh, M.; Nadhem, S.; Soumaya, Z.; Najiba, Z.; Raoudha, E.G. Antioxidant and antimicrobial properties of the extracts from Nitraria retusa fruits and their applications to meat product preservation. Ind. Crop. Prod. 2014, 55, $295-303$. [CrossRef]

11. Turtoi, M. Replacement of Nitrites (Nitrites) in Meat Products. In: MeatMilk Journal [online]. Bucharest. 2015. Available online: https:/ / www.meat-milk.ro/inlocuirea-azotitilor-nitritilor-in-produsele-din-carne/ (accessed on 15 September 2021). (In Romanian)

12. Lombraña, J.I. Fundamentals and Tendencies in Freeze-Drying of Foods. In Advances in Food Dehydration, 1st ed.; Ratti, C., Ed.; CRC Press: Boca Raton, FL, USA, 2008; pp. 209-235. [CrossRef]

13. Fellows, P. Freeze drying and freeze concentration. In Food Processing Technology: Principles and Practice, 4th ed.; Woodhead Publishing/Elsevier Science: Kent, UK, 2017; pp. 929-940.

14. Ratti, C. Hot air and freeze-drying of high-value foods: A review. J. Food Eng. 2001, 49, 311-319. [CrossRef]

15. Barley, J.; SP Scientific. Basic Principles of Freeze Drying. 2020. Available online: https://www.spscientific.com/freeze-dryinglyophilization-basics / (accessed on 2 June 2021).

16. Raț, A.M.; Muste, S.; Pop, C.; Rotar, A.M.; Nistor, A.L.; Chiș, M.S. Characterization of different plant extract types obtained from two varieties of basil (Ocimum Basilicum L.). Hop Med. Plants 2020, 1-2, 246-253.

17. Cioroi, M.; Dumitriu, D. Studies on total polyphenols content and antioxidant activity of aqueous extracts from selected Lamiaceae species. Ann. Univ. Dunarea Jos Galati Fascicle VI. Food Technol. 2009, 34, 42-46.

18. Leahu, A.; Damian, C.; Oroian, M.; Miclescu, V.; Ropciuc, S. Variation in content of antioxidant and free radical scavenging activity of basil (Ocimum basilicum), dill (Anethum graveolens) and parsley (Petroselinum sativum). Food Environ. Saf. 2013, XII, 347-353.

19. Aburigal, Y.A.A.; Mirghani, M.E.S.; Elmogtaba, E.Y.; Sirible, A.A.M.; Hamza, N.B.; Hussein, I.H. Total phenolic content and antioxidant capacity of basil (Ocimum basilicum L.) leaves from different locations. Int. Food Res. J. 2017, 24, S378-S381.

20. Chan, E.W.C.; Kong, L.Q.; Yee, K.Y.; Chua, W.Y.; Loo, T.Y. Antioxidant and antibacterial properties of some fresh and dried Labiatae herbs. Free. Radic. Antioxid. 2012, 2, 20-27. [CrossRef]

21. Słowianek, M.; Leszczyńska, J. Antioxidant properties of selected culinary spices. Herba Pol. 2016, 62, 29-41. [CrossRef]

22. Petkova, N.; Ivanov, I.; Raeva, M.; Topuzova, M.; Todorova, M.; Denev, P. Fructans and antioxidants in leaves of culinary herbs from Asteraceae and Amaryllidaceae families. Food Res. 2019, 3, 407-415. [CrossRef]

23. Khezrilu, B.J.; Heidari, R. The evaluation of antioxidant activities and phenolic compounds in leaves and inflorescence of Artemisia dracunculus L. by HPLC. J. Med. Plants 2014, 13, 41-50.

24. Predescu, C.; Papuc, C.; Ștefan, G.; Petcu, C. Phenolics content, antioxidant and antimicrobial activities of some extracts obtained from Romanian summer savory and Lebanon wild thyme. Sci. Work. Ser. C. Vet. Med. 2020, LXVI, 17-22.

25. Mašković, P.; Veličković, V.; Mitić, M.; Đurović, S.; Zeković, Z.; Radojković, M.; Cvetanović, A.; Švarc-Gajić, J.; Vujić, J. Summer savory extracts prepared by novel extraction methods resulted inenhanced biological activity. Ind. Crop. Prod. 2017, 109, 875-881. [CrossRef]

26. Coppo, E.; Marchese, A. Antibacterial activity of polyphenols. Curr. Pharm. Biotechnol. 2014, 15, 380-390. [CrossRef] [PubMed]

27. Bouarab-Chibane, L.; Forquet, V.; Lantéri, P.; Clément, Y.; Léonard-Akkari, L.; Oulahal, N.; Degraeve, P.; Bordes, C. Antibacterial Properties of Polyphenols: Characterization and QSAR (Quantitative Structure-Activity Relationship) Models. Front. Microbiol. 2019, 10, 829. [CrossRef] 
28. Ștefănescu, B.-E.; Călinoiu, L.F.; Ranga, F.; Fetea, F.; Mocan, A.; Vodnar, D.C.; Crișan, G. The Chemical and Biological Profiles of Leaves from Commercial Blueberry Varieties. Plants 2020, 9, 1193. [CrossRef]

29. Ștefănescu, B.-E.; Călinoiu, L.F.; Ranga, F.; Fetea, F.; Mocan, A.; Vodnar, D.C.; Crișan, G. Chemical Composition and Biological Activities of the Nord-West Romanian Wild Bilberry (Vaccinium myrtillus L.) and Lingonberry (Vaccinium vitis-idaea L.) Leaves. Antioxidants 2020, 9, 495. [CrossRef]

30. Sharma, H.; Mendiratta, S.K.; Agarwal, R.K.; Kumar, S.; Soni, A. Evaluation of antioxidant and anti-microbial activity of various essential oils in fresh chicken sausages. J. Food Sci. Technol. 2017, 54, 279-292. [CrossRef] [PubMed]

31. de Oliveiraa, T.L.C.; de Araújo Soaresa, R.; Ramosa, E.M.; das Graças Cardosob, M.; Alvesc, E.; Piccoli, R.H. Antimicrobial activity of Satureja montana L. essential oil against Clostridium perfringens type A inoculated in mortadella-type sausages formulated with different level soft sodium nitrite. Int. J. Food Microbiol. 2011, 144, 546-555. [CrossRef]

32. Gaio, I.; Saggiorato, A.G.; Treichel, H.; Cichoski, A.J.; Astolfi, V.; Cardoso, R.I.; Toniazzo, G.; Valduga, E.; Paroul, N.; Cansian, R.L. Antibacterial activity of basil essential oil (Ocimum basilicum L.) in Italian-type sausage. J. Consum. Prot. Food Saf. 2015, 10, 323-329. [CrossRef]

33. Tomović, V.; Šojić, B.; Savanović, J.; Kocić-Tanackov, S.; Pavlić, B.; Jokanović, M.; Đorđević, V.; Parunović, N.; Martinović, A.; Vujadinović, D. New Formulation towards Healthier Meat Products: Juniperus communis L. Essential Oil as Alternative for Sodium Nitrite in Dry Fermented Sausages. Foods 2020, 9, 1066. [CrossRef]

34. Ghendov-Moșanu, A. Biologically Active Compounds of Horticultural Origin for Functional Foods; Sturza, R., Ed.; Tehnica-UTM: Chisinau, Moldova, 2018; p. 236. (In Romanian)

35. Fierascu, I.; Dinu-Pirvu, C.E.; Fierascu, R.C.; Velescu, B.S.; Anuta, V.; Ortan, A.; Jinga, V. Phytochemical Profile and Biological Activities of Satureja hortensis L.: A Review of the Last Decade. Molecules 2018, 23, 2458. [CrossRef]

36. Ahmed, A.F.; Attia, F.A.; Liu, Z.; Li, C.; Wei, J.; Kang, W. Antioxidant activity and total phenolic content of essential oils and extracts of sweet basil (Ocimum basilicum L.) plants. Food Sci. Hum. Wellness 2019, 8, 299-305. [CrossRef]

37. Rappoport, Z. (Ed.) The Chemistry of Phenols, Parts 1 and 2; John Wiley \& Sons, Ltd.: Hoboken, NJ, USA, $2003 ;$ p. 1658.

38. Minatel, I.O.; Borges, C.V.; Ferreira, M.I.; Gomez, H.A.G.; Chen, C.Y.O.; Lima, G.P.P. Phenolic Compounds: Functional Properties, Impact of Processing and Bioavailability. Phenolic Compounds-Biological Activity. Marcos Soto-Hernandez, Mariana Palma-Tenango and Maria del Rosario Garcia-Mateos; IntechOpen: London, UK, 2017. Available online: https://www.intechopen.com/chapters/53128 (accessed on 2 June 2021).

39. GD No. 624 from 19-09-2020 Regarding the Approval of the Quality Requirements for Meat Preparations and Products. Available online: https:/ / www.legis.md/cautare/getResults?doc_id=123163\& (accessed on 2 June 2021).

40. Sandulachi, E. Water Activity in Food Products; Tehnica-UTM: Chisinau, Moldova, 2020; p. 160. (In Romanian)

41. Miklasińska-Majdanik, M.; Kępa, M.; Wojtyczka, R.D.; Idzik, D.; Wassik, T.J. Phenolic Compounds Diminish Antibiotic Resistance of Staphylococcus Aureus Clinical Strains. Int. J. Environ. Res. Public Health 2018, 15, 2321. [CrossRef] [PubMed]

42. Ivanova, V.; Stefova, M.; Chinnici, F. Determination of the polyphenol contents in Macedonian grapes and wines by standardized spectrophotometric methods. J. Serb. Chem. Soc. 2010, 75, 45-59. [CrossRef]

43. Brand-Williams, W.; Cuvelier, M.; Berset, C. Use of a free radical method to evaluate antioxidant activity. LWT 1995, 28, 25-30. [CrossRef]

44. Weinstein, M.P. Methods for Dilution Antimicrobial Susceptibility Tests for Bacteria that Grow Aerobically; Clinical and Laboratory Standards Institute (CLSI): Wayne, PA, USA, 2018; ISBN 978-1-56238-836-2.

45. Schwalbe, R.; Steele-Moore, L.; Goodwin, A.C. Antimicrobial Susceptibility Testing Protocols; CRC Press: Boca Raton, FL, USA, 2007; ISBN 978-1-4200-1449-5.

46. ISO 6658:2017. Sensory Analysis-Methodology—General Guidance. Available online: https://www.iso.org/standard/65519. html (accessed on 2 June 2021).

47. Bradley, R.L. Moisture and Total Solids Analysis. In Food Analysis; Springer: Boston, MA, USA, 2010.

48. ISO 4833-1:2013. Microbiology of the Food Chain-Horizontal Method for the Enumeration of Microorganisms-Part 1: Colony count at $30^{\circ} \mathrm{C}$ by the Pour Plate Technique. Available online: https:/ / www.iso.org/standard/53728.html (accessed on 2 June 2021).

49. ISO. ISO 24444:2010 Cosmetics-Sun Protection Test Methods-In Vivo Determination of the Sun Protection Factor (SPF). Available online: https:/ /www.iso.org/obp/ui/\#iso:std:iso:24444:ed-1:v1:en (accessed on 15 November 2018).

50. Sandulachi, E.; Rubțov, S.; Popescu, L. Microbiological Control of Food; Tehnica-UTM: Chisinau, Moldova, 2017. (In Romanian)

51. ISO 6579-1:2017. Microbiology of the food chain-Horizontal method for the detection, enumeration and serotyping of Salmonella-Part 1: Detection of Salmonella spp. Available online: https://www.iso.org/standard/56712.html (accessed on 2 June 2021).

52. Galețchi, P.; Buiuc, D.; Plugaru, S. Practical Guide to Medical Microbiology; Technical Bucharest: Chisinau, Moldova, 1997; pp. 86-99. (In Romanian)

53. Preparation of McFarland Turbidity Standards. Available online: https://microbeonline.com/preparation-mcfarland-turbiditystandards / (accessed on 2 June 2021). 